\title{
水田畦畔に植栽した在来種由来の園芸植物の被覆効果
}

\section{Effects of Covering of the Cultivars Originated from Native Species Introduced into Levee Slope around Paddy}

\author{
根本 正之* 宗吉 直子* 濱野 周泰* \\ Masayuki NEMOTO Naoko MUNEYOSHI Chikayasu HAMANO
}

\begin{abstract}
摘要 : 基盤整備後の棚田畦畔を自然に近いかたちで緑化する目的で，我国の在来種に由来する園芸植
物を畦畔法面に定植し、1 年間にわたりそれらの法面被覆過程を調查した。シロバナサギゴケ区では 成長の開始が早く，5月下旬には全面が被覆された。しかし秋季にはほとんどの親株が枯死した。キ チジョウソウやコグマザサは初期成長が遅く，処理区内に多くの雑草が発生した。しかしながら何度 か草刈りを行えば，秋季までには活着し法面を十分被覆した。土壤の水分状態に対応し，法面下部で はシロバナサギゴケの生育がよく，逆にコグマザサは生育が抑制された。
\end{abstract}

1.はじめに

山地や丘陵地などの斜面に階段状にひらかれた棚田は，今日そ の歴史的文化遺産としての価值が評価されるようになってきた ところで数多くの小規模で不整形の水田から構成される棚田は, 全国各地で現在でも稲作の機械化之効率化を阻む最大の要因であ るとの立場から，隣接する田面を結合して規模の拡大を計る基盤 整備事業の対象となっている。皮肉にもこの基盤整備によって水 田区画間の段差が拡大，また畦畔の法面に安定勾配を与えたため, 従前の畦畔と比べ面積の広い法面が出現することとなった。

そのため導入の容易な牧草類や外来のグラウンドカバープラン ツによる法面の土䁃侵食防止之，侵入雑草の草刘りの軽減を目的 とした緑化が盛んとなった ${ }^{2)}$ 。しかしこのような外来種はその生 育地が限られている在来種と比較して，侵食防止に適している種 ほど生育が旺盛なため，周辺地域にまで逸脱し，雑草化する危険 性が高い。また伝統的な棚田に象徵される農村景観とはかなり異 質なものも多い。一方，在来種は病害虫に強く，植生も特定の環 境条件下で安定しているものが多いと言われている2〕。

本研究では，基盤整備後の法面に自然に近い形で植生を復元す る上での基礎的知見を得るため，我国在来のキチジョウンウ (Reineckea carnea) 及び在来草種からグラウンドカバープラ ンッとして選抜された園芸植物であるシロバナサギゴケ (Mazus miquelii f. albiflorus) とコグマザサ（Sasaella kogasensis var.gracillima）を基盤整備後の畦畔法面に植え 込み，その成長過程を追跡調查した。

\section{2. 調查地および調查方法}

\section{(1) 試験区の設定}

供試植物の生育調査は, 房総半島の中心部に位置する上総亀山 に隣接した君津市豊田にある，基盤整備後 8 年経過した大森畜産 所有の水田畦畔で行った。当地の標高は約 $80 \mathrm{~m}$ で, 隣接する坂 畑の 1999 年 10 月から 2000 年 9 月までの平均気温は $14.3^{\circ} \mathrm{C} て ゙$, 降水量は $1663 \mathrm{~mm}$ である。

北向きの長さ約 $30 \mathrm{~m}$, 傾斜 $45^{\circ}$, 斜面長 $8.3 \mathrm{~m}$ の畦畔法面に 1999 年 10 月 17 日, あらかじめ直径 $9 \mathrm{~cm}$ のビニールポットで育 苗しておいたシロバナサギゴケ，キチジョウソウ及びコグマザサ の苗を，法面の除草を行った後，それぞれ幅 $2 \mathrm{~m}$ ，長さ $8.3 \mathrm{~m}$ の 法面の全面に等間隔に定植した。植栽密度はシロバナサギゴケと
コグマザサは 16 株 $/ \mathrm{m}^{2}$, 他の 2 種より個体サイズのいくぶん大 きかったキチジョウソウは 9 株 $/ \mathrm{m}^{2}$ とし，いずれも千鳥植えとし た。また供試植物を植栽しない場所を対照区とし， 2 反復で試験 区を設定した。供試植物はいずれも関東地方の自生地から採集し た株を増殖したものである。

\section{(2) 調査の方法}

1999 年 10 月 17 日の定植直後, 供試した各種から，それぞれ 20 個体をランダムに抽出し，個体別の長径と短径及び草高を測 定した。翌 2000 年 3 月 28 日, 各処理区とも法面に直角に 1 本の テープを張り，テープに接触した個体の長径，短径及び草高を測 定した。また別に, 法面の上, 中, 下に $50 \mathrm{~cm} \times 50 \mathrm{~cm}$ の枠を設け, 枠内供試個体の長径と短径及び草高を測定後, 枠内に発生した総 ての雑草を除去した。上記の個体別調査と雑草除去は同時におよ そ $2 \sim 3$ 週間の間隔で 10 月 7 日まで行った。

処理区全体の除草は 5 月 15 日と 8 月 7 日の計 2 回行った。こ れとは別に 7 月 10 日と 10 月 10 日には上，中，下の $50 \mathrm{~cm} \times 50 \mathrm{~cm}$ 枠に隣接して新たに $50 \mathrm{~cm} \times 50 \mathrm{~cm}$ の方形枠を 2 力所設け，そこに 出現した総ての雑草を 7 月 10 日は地上 $10 \mathrm{~cm}$ の高さで, 10 月 7 日 は地際から刈取り, 草種別の乾重量を測定した。また 10 月 10 日 には毎回雑草を除去しておいた枠内のすべての供試個体を堀取り, 各々, 葉面積を測定した後, 地上部と地下部に分けて乾重量を測 定した。乾重量は $80^{\circ} \mathrm{Cで} 48$ 時間通風乾燥して得た。

供試植物と水分競合を起こすことが予想された多くの雑草が生 育している法面の土㙵水分環境の変化を知るため, 土堙水分セン サKDC-S5 (コーナシステム社製) を斜面の上部からほぼ等間 隔に 4 ヶ所設置し，8月 10 日より 9 月 4 日まで各地点別の土壌 水分量の経時的な変化を観測した。雑草の根圈は $20 \mathrm{~cm}$ 付近まで

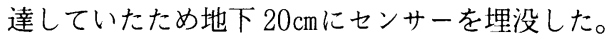

供試個体の成長過程を解析するための量的測度として, 個体別 の長径と短径の値から求められる楕円の面積をその広がりとして 表示した。また広がりと草高の積を体積近似值とみなし，この值 から推定地上部現存量を求めた。

\section{3. 結果}

（1）定植した供試植物の生育パターン

テープに接触した全個体の広がりの平均値から算出した各種別 の生育パターンを図 1 に示した。なお，植栽時の供試個体の広が

·東京農業大学地域環境科学部造園科学科 


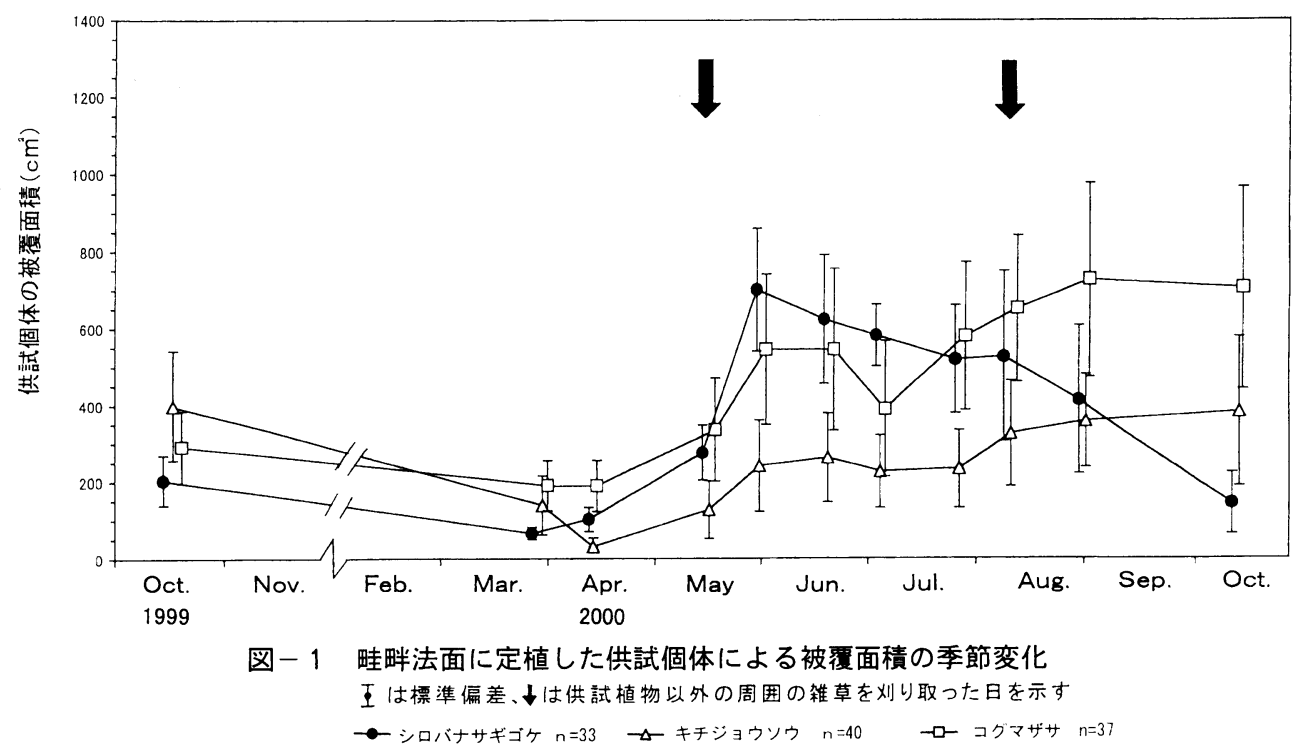

りと草高から求めた推定地上部現存量はシロバナサギゴケ, キチ ジョウソウ，コグマザサがそれぞれ $1101 \mathrm{~cm}^{3}, \quad 5855 \mathrm{~cm}^{3}, \quad 2663 \mathrm{~cm}^{3} て ゙$ あった。いずれの種も定植した 10 月以降, 冬季間は葉の一部枯 死によって個体の広がりは縮小した。

シロバナサギゴケは他種よりいくぶん早く，3月下的より成長 を開始した。5 月下旬には広がりが最大となり, 雑草除去区では 枠内を完全に被覆した。しかし夏季には成長が著しく抑制され,

10 月上旬には定植した親株の大半は枯死した。この時点で生存 していたのは, 親株の周辺にランナーによって広がった僅かばか りの子株だけであった。

キチジョウソウは定植時点での広がりまで回復するのに約 1 年 かかった。秋季に入っても僅かに成長したが, 短期間で法面を完 全に被覆することはなかった。

コグマザサはシロバナサギゴケよりやや遅れて成長を開始した が，5月中旬には定植時とほぼ同じ広がりまでに回復した。7月 上旬には日照不足のためか, キチジョウソウとコグマザサの成長 が停滞ぎみとなった。とくにコグマザサについては，この時期が 旧桿と当年生桿が入れ代わる時期でもあったことから, 成長の抑 制が顕著になったものと考えられる。コグマザサはその後, 再び 生育し続け, 広がりが 3 種のうちで最大となった。また他種と比 較し，植栽苗によるバラッキが大きかった。

\section{（2）法面上の位置と供試植物の推定地上部現存量}

法面に張ったテープに接触した個体別の推定地上部現存量を上 部から順番に示したのが図 2 である。定植の後まだ成長が見られ なかった 3 月 28 日の值は, 多少のバラッキは見られるものの特 別な傾向は認められない。成長が旺盛となった 6 月 17 日の值は, シロバナサギゴケでは下部に向かうと高くなる傾向を示した。一 方, キチジョウソウにはその位置によって成長が異なるという傾 向は認められなかった。

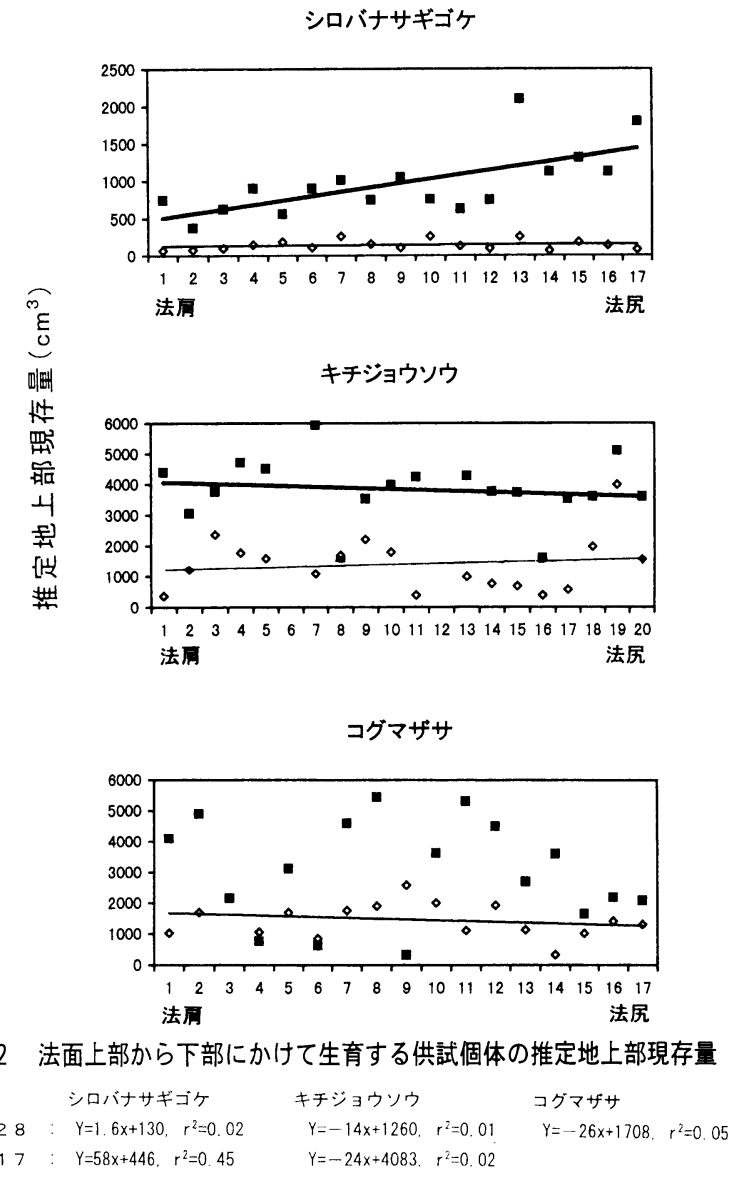

表ー1 10 月 10 日にサンプリングした供試植物の部位別乾物重量及び葉面積

\begin{tabular}{|c|c|c|c|c|c|c|c|c|c|}
\hline & \multicolumn{3}{|c|}{ シロバナサギゴケ } & \multicolumn{3}{|c|}{ キチジョウソウ } & \multicolumn{3}{|c|}{ コグマザサ } \\
\hline & 上 & 中 & 下 & 上 & 中 & 下 & 上 & 中 & 下 \\
\hline 葉（g $g_{D W} /$ 個体） & 0.46 & 0.83 & 0.66 & 4.22 & 8.71 & 5.91 & 13.38 & 10.20 & 1.96 \\
\hline 茎 $\left(\mathrm{g}_{\mathrm{OW}} /\right.$ 個体) & 0 & 0 & 0 & 0 & 0 & 0 & 7.36 & 5.50 & 1.81 \\
\hline 根 ( $\left(\mathrm{g}_{\mathrm{OW}} /\right.$ 個体) & ※ & $※$ & $※$ & 9.70 & 10.90 & 21.59 & 31.53 & 13.76 & 11.75 \\
\hline 葉面積指数 $\left(\mathrm{cm}^{2} / \mathrm{cm}^{2}\right)^{* * *}$ & $※$ & $※$ & $※$ & 0.97 & 1.47 & 1.34 & 2.48 & 2.19 & 2.24 \\
\hline
\end{tabular}

※ シロバナサギゴケの根重及び萧面積は欠欠測

葉面積指数は，供試個体の葉面積をその広がりで除した值で示した 
供試したコグマザサの個体サイズはほぼ一定であったが，それ は親株を機械的に分割したものであり，質的にはかなりのバラッ キがあったと考えられる。このような個体の質的差異がその後の 成長に影響し，個体差を大きくしたと推定される。コグマザサは その周用に空間があってもシロバナサギゴケのようにただちにそ れを埋めつくすような成長パターンを示さない。そのため，コグ マザサ個体間に生じた裸地のサイズはさまざまで, 生育型の異な る色々な雑草種が侵入した。その結果, コグマザサ周辺の環境は 個体によって大きく異なった。

図 2 に示した供試個体の成長は周辺部に生育する侵入雑草に影 響される場合もあるので，法面の上，中，下に設けた除草枠内の 供試植物を 10 月 10 日に総てサンプリングし, それぞれ部位別の 乾物重と葉面積指数を測定した（表 1)。表 1 から明らかなよう に，10月上旬になるとシロバナサギゴケは法面上の位置のいか んを問わず大半が枯死，僅かに子株が散在するだけで，現存量は 極めて小さかった。一方，キチジョウソウは上部の枠内個体の生 育が若干劣っていた。逆にコグマザサでは明らかに上部の生育が 旺盛であり，下部ではほとんど成長していないことがわかった。 表 1 に示した葉面積指数は供試個体の葉面積をその広がりで除し たものである。上，中，下で葉面積指数の值はほとんぞ差がない が，個体重の值から下部個体の広がりは極めて小さかったことが わかる。そのため, 法面下部ではコグマザサの葉が，特定の場所 に集中する傾向を示した。そして，コグマザサの葉で覆われてい ない部分には，湿性雑草の発生がみられた。

\section{（3）畦畔法面の土壤水分量の推移}

法面上部から下部にかけての 4 ヶ所に設置した水分センサーで 得られた $\mathrm{pF}$ 值の，測定日ごとに 1 時間おきに得られた值の平均 值を求め, その推移を図 3 に示した。ところで法面中部の除草枠 は上部から 2 番目と 3 番目のセンサーの中間に位置していた。そ こで図 3 の中部の值は枠内供試個体や, その周辺部に発生した雑 草との関係をみるため, 2 番目と 3 番目で得られた平均值で示し てある。

当該畦畔の圃場容水量が $\mathrm{pF} 1.5 \sim 2.0$ の間にあるとするなら ば3.4), 図 3 より明らかなように法面上部は測定期間中，常に乾燥 ぎみであり，逆に法面下部では特に降雨後はかなり過湿ぎみとなっ ていることが判明した。

\section{（4）畦畔法面に発生した雑草の様相}

対照区を含む処理区内に発生した雑草のうち，各区で優占した 上位 3 種の地上部見存量を図 4 に示した。供試個体は除草を十分 行っている戋場から導入したものであり, 供試苗のポット内には 雑草の発生は認められなかった。従って試験区内に発生した雑草 は総てその周辺から侵入したものと考えられる。図の左側は 5 月 15 日の区全体の除草以降 7 月 10 日までに発生した雑草量を, 右 側は 8 月 7 日の全体除草以降 10 月 10 日までに発生したものであ る。

草刈りの間隔は両者であまり変わらないが，刈取り後に発生し た雑草の様相は両者で明らかに異なった。すなわち，7月に一部 の区で優占していたメヒシバが 10 月になると法面の上, 中部の ほぼ全面を覆うようになった。下部では対照区にメヒシバが発生 したが，その現存量は上，中部に比べ少なかった。上，中部では， 夏から秋に成長のピークがみられる一年生雑草のメヒシバやオオ アレチノギク，ヒメムカショモギなど Erigeron 類が多かった。 下部では, 多年生のスギナなどの湿性雑草とセイタカアワダチン ウの芽生えが多かった。

処理区別にみると，シロバナサギゴケ区の雑草発生の様相が 7 月と 10 月ではかなり違うことがわかる。7月はまだシロバナサ ギゴケの被覆率が大きかったので雑草の発生量もそれほどでなかっ たが, 親株の枯死した 10 月には上, 中部でメヒシバが圧倒的に

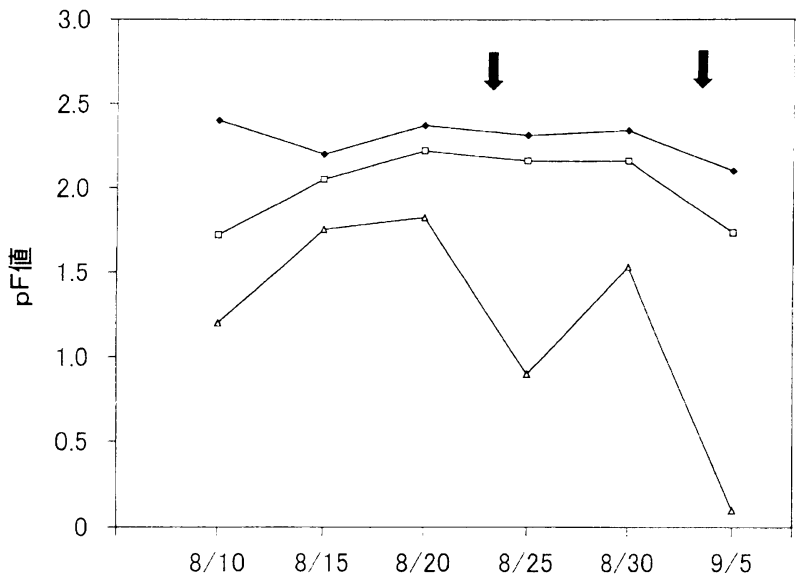

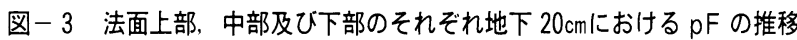

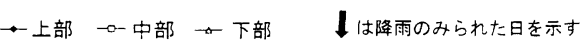
中部の値は，2 番目と 3 番目のセンサーで得られた值の平均值で示した
7月
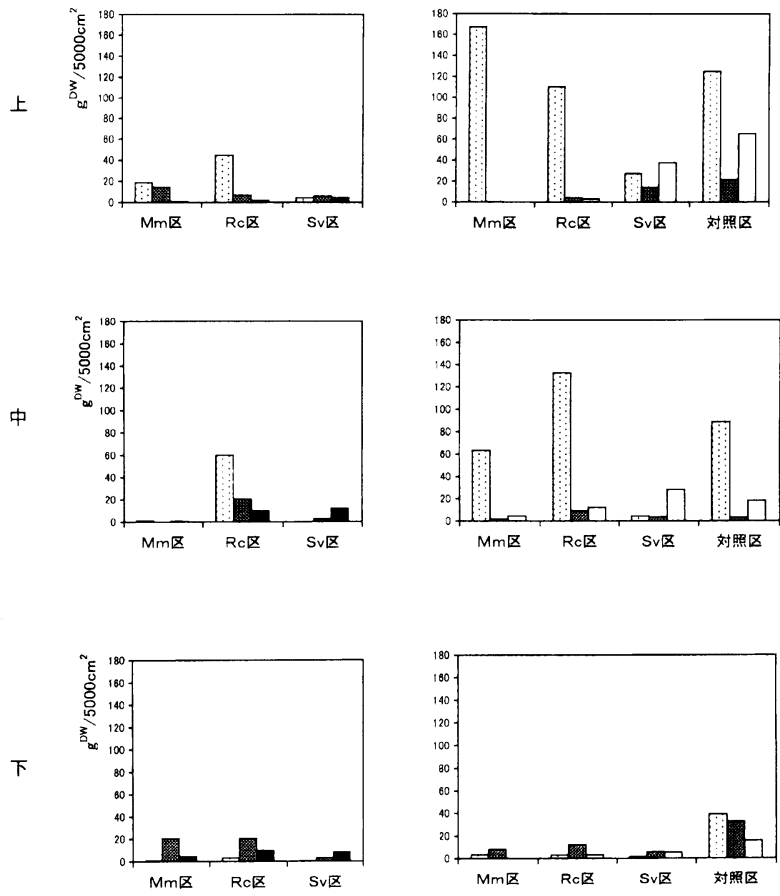

図-4 法面の異なる場所に発生した優占雑草のうち上位 3 種の地上部現存量

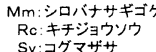

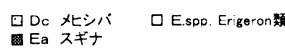

ロ Сс ツュクサ

優占，上部のメヒシバは対照区より多かった。比較的成長の遅かっ たキチジョウソウ区は三者の中で被覆率が最も低く, 雑草発生量 は多かった。コグマザサ区は全面に雑草が発生しなかったが，葉 層下でロゼットを形成し後に抽苔してくる Erigeronタイプの雑 草がめだった。

\section{4. 考察 \\ （1）供試植物の法面被覆力}

本試験に供試した植物は我国の自生種あるいはその forma で 
あり，現在，在来種のグラウンドカバープランッとして栽培され ている2゙。シロバナサギゴケはほふく茎で，キチジョウソウとコ グマザサは根茎によって親株の近くから密生していき生育地を拡 大する陣地拡大型戦略を示す ${ }^{5}$ 。いずれも小型で定植後の管理が 容易であるとの理由からグラウンドカバープランツとして期待さ れている。

シロバナサギゴケの原種であるムラサキサギゴケを用いた試験 では, それが地表面を完全に覆うため, 他から侵入してくる雑草 発生量が著しく少なかったという ${ }^{6)}$ 。また水田畦畔などのかなり 湿った場所に生え"), シロバナサギゴケの場合にはある程度の踏 圧にも耐えるという ${ }^{8)}$ 。

キチジョウソウは関東以西, 四国, 九州の樹林内の陰地で繁茂 している ${ }^{8}$ 。そのため日当たりが良すぎると葉焼けを起こすこと があるが，北向きの法面など半日陰の場所には適しているらしい。 繁殖力は強く，適湿地から湿地まで生育可能である ${ }^{8)}$ 。

コグマザサは関東地方に多く栽培されているアズマザサ属のサ サである。稈の高さは20 40cmで母種のコガシアズマザサより かなり低い。やや生育は遅いが，根茎で増殖し，此較的密生する ため雑草の発生が少ないといゔ2)。また排水良好な肥沃で湿った 半日陰を好み, 刈取りや踏圧にも強い ${ }^{2.97}$ 。

このように見てくると, 本試験の供試植物は, いくつかの付帯 条件はあるものの，おしなべて畦畔法面の被覆力に優れていると の報告が多い。しかしながら実際の畦畔法面にそれらを定植し, 一年間にわたって生育パターンを調查した結果, 供試植物の被覆 力は必ずしも一定ではなく，シロバナサギゴケは初期成長は旺盛 でも秋季に中心部が枯死するし，コグマザサやキチジョウンウで は法面の被覆にかなりの時間を要するので侵入してくる雑草を何 度か刚り取る必要があることが明らかとなった。

（2）法面の被覆力に係わる諸要因

本試験の結果から, 供試植物の被覆力に影響を及ぼす要因は, (1)供試植物に固有の生理生態的特性之, (2)定植した法面の土壌環 境及び(3)侵入雑草の発生消長に係わるものに分けることができた。 (1)シロバナサギゴケは夏の乾燥と高温による生育阻害を起こし
たが，枯死するには至らなかった。しかし秋季に向かうとほとん ど総ての親株が枯死し, 被覆効果が失われた。他の場所でもこの ような現象が観察されることから，これは種に固有の生態的特性 と考えられる。コグマザサ区の雑草発生量は少なかった。しかし コグマザサは定植後速やかに全面を被覆することはなく，小さな ギャップが多数存在している間は, 始めロゼット葉を形成し, 後 に抽苔してくる Erigeron などの大型の陣地強化型雑草 ${ }^{5}$ が繁茂 する危険性があった。キチジョウンウは三者の中で活着に要する 時間が最も長く, 侵入雑草の影響を強く受けた。しかしながらこ の種は半日陰を好むので, むしろ雑草が繁茂していた方が, 生育 に都合がよかったとも考えられる。

次に(2)土壌環境に係わる要因として，まず法面の土壌水分量を あげることができる。法面の斜面長が $10 \mathrm{~m}$ 近くなると，部位に よって水分量がかなり異なることが判明した。そのため, キチジョ ウソウのように土壌水分量の違いにあまり反応しない種はともか く, コグマザサでは法面下部の過湿土壤で根系の発達が阻害され た。逆にシロバナサギゴケは下部の生育がよかった。

(3)土䁃水分の違いは侵入雑草の発生消長にも反映された。すな わち上, 中部ではメヒシバの発生量が多く, 供試植物を庇蔭した。 法面上部の一部でコグマザザの生育が悪かったのは, 周辺にメヒ シバなどの雑草が発生したためと考えられる。法面下部には湿性 雑草がみられたが，発生量は上部ほどではなかった。上述のよう に，今回供試した植物はいずれもグラウンドカバープランッとし て一長一短があることが明らかとなった。シロバナサギゴケ以外 の 2 種についてはさらに追跡調査を行い，それらの生態的特性の 全貌を明らかにしていく必要があると考えられる。

\section{謝辞}

本研究に関わる試験は大森畜産(有)加埔場を借用, 供試植物 を提供いただいて行ったものである。同社の大森斎社長，大森一 憲氏には大变お世話になりました。また東京農業大学造園学科ラ ンドスケープエコロジー及び造園樹木学研究室の学生諸君には野 外調査にご協力いただいた。併せ，感謝の意を表します。

\section{引用文献}

1) 中島峰広 (1999): 日本の棚田一保全 への取り組み一: 古今書院, $240 \mathrm{pp}$.

2 ) 有田博之・藤井義晴（1998）: 畦畔之 圃場に生かすグラウンドカバープラン ツ: 農文協, $170 \mathrm{pp}$.

3 ) 渡辺裕・寺沢四郎（1977）：生態学研 究法講座 29 環境測定法 III 一農地土 壌一：共立出版, $192 \mathrm{pp}$

4 ) 山根一郎 (1982)：改訂新版 土壌学
の基礎と応用：農山漁村文化協会, 270pp.

5 ) Nemoto, M. and J. Mitchley (19 95): Weed species diversity and its conservation value : Proc. $15^{\text {th }}$ Conf. APWSS I (A), 394-399

6 ）根本正之・大塚俊之（1998）：農耕地 周辺に自生する小型植物の被覆による 雑草抑制効果: 雑草研究 43(1), 2634
7 ) 沼田真・吉沢長人 (1978)：新版・日 本原色雑草図鑑：全国農村教育協会, $414 \mathrm{pp}$.

8 ) 塚本洋太郎総監修（1994）: コンパク 卜版・園芸植物大辞典 1 ：小学館, $1524 \mathrm{pp}$

9 ）鈴木貞雄（1978）：日本夕ケ科植物総 目録: 学習研究社, $383 \mathrm{pp}$.

Summary : In order to restore the seminatural vegetation, Mazus miquelii f. albiflorus, Reineckea carnea and Sasaella kogasensis var.gracillima, all of them are native in Japan, were transplanted on the levee slope which was constructed as a part of farmland consolidation. The growth and the slope covering effects of these test plants were investigated almost throughout a year. M.miquelii developed leaves in early spring and completely covered the ground surface in May. But in September most leaves were suddenly disappeared. R. carnea and S. kogasensis var.gracillima were slow in growing at early stage and the space remained was occupied by weed plants. Under the mowing condition, however, both test species produced the well-developed leaf layer in autumn season. M.miquelii grew well at bottom of the slope in response to the saturated water condition in soil. In contrast to M. miquelii, the growth of S. kogasensis var. gracillima was suppressed at the bottom. 